\title{
Managerial Stock Ownership and the Maturity Structure of Corporate Debt
}

\author{
SUDIP DATTA, MAI ISKANDAR-DATTA, and KARTIK RAMAN*
}

\begin{abstract}
This study documents that managerial stock ownership plays an important role in determining corporate debt maturity. Controlling for previously identified determinants of debt maturity and modeling leverage and debt maturity as jointly endogenous, we document a significant and robust inverse relation between managerial stock ownership and corporate debt maturity. We also show that managerial stock ownership influences the relation between credit quality and debt maturity and between growth opportunities and debt maturity.
\end{abstract}

THE IMPORTANCE OF LEVERAGE AND DEBT MATURITY STRUCTURE CHOICE in alleviating manager-shareholder agency conflicts is well recognized in the finance literature. These vital decisions are at the discretion of top managers who are expected to make optimal (value-maximizing) financing choices on behalf of the shareholders. However, given the separation of ownership and control, managers cannot be expected to voluntarily choose the optimal debt maturity structure or leverage and self-impose monitoring unless there is an incentive mechanism to align managerial and shareholder interests. It is clear, therefore, that these decisions themselves are subject to an agency problem of managerial discretion.

Managerial stock ownership can be effective in aligning the interests of managers and shareholders to mitigate such agency problems (see, e.g., Jensen and Meckling (1976)). We argue that the conflict between managers and shareholders over the maturity structure of debt arises from the inherent preference of self-interested managers for less monitoring. Our study adds a new dimension to the recently growing body of literature on capital structure choice in the presence of agency conflicts. By examining how managerial stock ownership determines corporate debt maturity structure, we provide evidence on an important, yet unaddressed, issue that is at the confluence of the capital structure and corporate governance literatures.

Earlier capital structure studies emphasize the role of debt in reducing agency problems between managers and shareholders (see, e.g., Jensen and

*Datta and Iskandar-Datta are in the Department of Finance at the School of Business Administration, Wayne State University; Raman is in the Department of Finance at Bentley College. Datta acknowledges support from the T. Norris Hitchman Endowed Chair. We thank Husayn Shahrur, the seminar participants at the University of Alabama and Wayne State University, and especially the referee and Rob Stambaugh (the editor) for valuable comments. The usual disclaimer applies. 
Meckling (1976), Grossman and Hart (1982), Jensen (1986), and Stulz (1990)). More recently, researchers recognize that in addition to the leverage decision, more detailed aspects of financing decisions, such as the debt maturity structure choice, play an important role in reducing agency conflicts. Barclay and Smith (1995), Guedes and Opler (1996), and Stohs and Mauer (1996) empirically examine the determinants of the maturity structure of corporate debt. ${ }^{1}$ While informative, these and related previous studies have largely ignored a key issue related to corporate debt maturity choice by assuming perfect alignment of manager-shareholder interests.

Myers' (1977) seminal model on the determinants of corporate borrowing, which recommends shorter maturity debt to alleviate the "underinvestment" problem, also assumes perfect manager-shareholder interest alignment. In the face of favorable private information, managers are expected to avoid locking in debt financing with long-maturity debt; therefore, if managers have the right incentives, they are expected to choose short-maturity debt with the associated lower agency cost. Short-maturity debt has the additional benefit of reducing the agency costs of managerial discretion by subjecting managers to more frequent monitoring by underwriters, investors, and rating agencies at issuance. As short-term debt comes up for frequent renewal, Stulz (2000) states that "short-term debt can be an extremely powerful tool to monitor management." In addition, Rajan and Winton (1995) show that short-term debt gives lenders the flexibility to effectively monitor managers with minimum effort. Thus, managers with weak interest alignment with shareholders and inherent affinity for greater autonomy would prefer to entrench themselves by choosing long-term debt to reduce the potential discipline of external monitoring. Based on the preceding argument, we contend that when the alignment of interests between managers and shareholders is weak, managers would be more inclined to make suboptimal debt maturity structure choices. Specifically, in such a scenario, they would choose long-term debt over short-term debt even though the associated agency costs of taking such an action are higher.

Using a sample of 4,514 firm-year observations during the period January 1 , 1992 to December 31, 1999, we study the link between managerial stock ownership and corporate debt maturity. Following Barclay, Marx, and Smith (2003) and Johnson (2003), we use the two-stage least squares regression methodology to model the simultaneous choice of leverage and debt maturity. After accounting for the endogeneity between leverage and debt maturity choice

\footnotetext{
${ }^{1}$ Barclay and Smith (1995) document that firms with growth opportunities prefer short-term debt while larger firms and firms with low credit ratings tend to employ long-term debt. Guedes and Opler (1996) find that large firms with investment grade debt generally finance at the short end and the long end of the maturity spectrum, whereas speculative grade firms borrow in the middle of the maturity spectrum. They argue that firms with speculative grade debt prefer to issue the longest maturity debt, possibly to avoid the risk of costly liquidation, but they are screened out of the long end of the bond market due to a moral hazard problem. Kale and Noe (1990) show that a separating equilibrium can exist in which high quality firms issue short-term debt and low quality firms issue long-term debt. Stohs and Mauer (1996) show that larger and less risky firms are more likely to use long-term debt and, in contrast to Barclay and Smith (1995), find mixed support for the inverse relation between debt maturity and growth opportunities.
} 
and controlling for leverage (predicted from the first-stage regression), asset maturity, growth opportunities, firm size, term structure, bond rating, and other issuer characteristics, we document a statistically significant inverse relation between managerial stock ownership and debt maturity. Our analysis shows that managers with higher stock ownership, and therefore better incentive alignment with shareholders, choose a larger proportion of short-maturity debt. The economic implication of this result is that an increase in managerial stock ownership from the median to the $95^{\text {th }}$ percentile is expected to shorten the percentage of total debt maturing in 3 years or more by $4.90 \%$. This finding establishes for the first time the role of managerial stock ownership in determining corporate debt maturity structure choice beyond the basic capital structure (debt-equity choice) decision.

Our central hypothesis of an inverse relation between managerial stock ownership and debt maturity allows us to build on Diamond's (1991) argument that debt maturity increases with the liquidity risk of the firm. We extend Diamond's proposition by reasoning that manager-shareholder interest alignment is expected to influence the relation between liquidity risk and debt maturity. Our analysis indicates that managers with lower ownership choose longer maturity debt even when liquidation risk is low. This new finding related to Diamond's (1991) proposition extends our understanding of the relation between liquidity risk and the choice of debt maturity.

Based on our main hypothesis, we also examine the influence of managerial stock ownership on the relation between growth opportunities and maturity structure of debt. Consistent with the results in Stohs and Mauer (1996) and Johnson (2003), our analysis shows that firms with high-growth opportunities have more long-term debt in their capital structure. Importantly, among firms with low-growth opportunities, we find that managers with high equity ownership choose a significantly higher proportion of short-maturity debt than their counterparts with low managerial stock ownership. This finding suggests that managerial stock ownership is effective in facilitating external monitoring, specifically at firms with greater agency costs of managerial discretion.

The paper proceeds as follows. In Section I, we develop the hypothesis that relates managerial stock ownership and corporate debt maturity structure choice. We also present two propositions that emerge from our main hypothesis and extend our current understanding of the relation between liquidity risk and debt maturity, and between growth opportunities and debt maturity, when managerial stock ownership is taken to be a determinant of corporate debt maturity structure choice. Section II presents the sample formation process and data description. The empirical findings are presented in Section III. We summarize our results and draw conclusions in Section IV.

\section{Managerial Stock Ownership and Debt Maturity Structure}

Berger, Ofek, and Yermack (1997) find that firms with weak managerial incentives avoid high levels of leverage, while Novaes and Zingales (1995) show that the optimal leverage for shareholders differs from that chosen by 
entrenched managers. When issuing debt, managers have discretion not only over their firm's leverage choice but also over debt maturity. Self-interested managers with low or no equity ownership are apt to shun external pressures arising from frequent monitoring by debt markets. As a result, managers may deviate from the optimal debt maturity choice. Since long-term debt insulates managers from external monitoring for a longer period of time than short-term debt, managers with low or no equity ownership would tend to prefer longer maturity debt.

Managerial equity ownership helps align the interests of managers and shareholders, and hence should alleviate debt-related agency problems. A stronger manager-shareholder interest alignment can reduce the agency costs that arise from the preference of self-interested managers for longer maturity debt and less scrutiny. We reason that stock ownership provides managers the incentives to choose a debt maturity structure that facilitates more frequent monitoring. Hence, we expect an inverse relation between managerial stock ownership and debt maturity. This is the central hypothesis that we propose and test in this study.

Another contribution of this study is the extension of Diamond's (1991) proposed relation between liquidity risk and debt maturity by relaxing his assumption of perfect manager-shareholder interest alignment. Diamond argues that firms with low liquidity risk (high credit quality) are expected to have shorter maturity debt than firms with high liquidity risk (low credit quality) because firms with low liquidity risk face lower risk of inefficient liquidation. Given the monitoring benefits of short-maturity debt, the choice of debt maturity entails a trade-off between the benefits of external monitoring by the debt market and the cost of inefficient liquidation. ${ }^{2}$ We add another dimension to the debt maturity choice trade-off by recognizing that managerial stock ownership is expected to play a crucial role in influencing the relation between liquidity risk and debt maturity.

For high credit quality (low liquidity risk) firms, the benefits of monitoring are expected to dominate the expected costs of inefficient liquidation. Given that liquidity risk is less of a concern for these firms, managers are expected to choose short-term debt with the associated monitoring benefits if their interests are aligned with those of shareholders as suggested by our main hypothesis. However, the inherent tendency to avoid being monitored may prompt managers with low ownership to choose long-term debt even if the liquidity risk is low. Based on the above reasoning, for firms with low liquidity risk, we expect a pronounced difference between the debt maturity structures of firms with high and low managerial stock ownership.

\footnotetext{
${ }^{2}$ Borrowing short term, as opposed to long term, generates higher costs in the form of flotation costs (such as investment bank fees and legal fees), the cost of managerial time spent on more frequent debt issuances, and the potential costs of illiquidity as the short-term debt comes due. Thus, the benefits from shorter-term debt need to be large enough to offset the additional costs of frequent issuance. In the same vein, Diamond (1991) predicts that, when confronted with debt maturity choices, firms balance the costs of liquidity risk against the gains achieved from shortterm debt.
} 
For poor credit quality firms, high liquidity risk is likely to outweigh the benefits of monitoring associated with short-term debt. Therefore, for these firms, the prospect of costly liquidation will force managers with high ownership to choose long-term debt, while those with low ownership will also choose long-term debt regardless of whether it is in their self-interest to avoid being monitored or to avoid costly liquidation. Moreover, Diamond (1991) predicts that firms with very low credit quality will be forced to borrow short-term as they get screened out of the long end of the maturity spectrum. Thus, for low credit quality firms, the influence of managerial stock ownership on debt maturity choice is unclear. In sum, our reasoning suggests that the inverse relation between managerial stock ownership and debt maturity is expected to be stronger for high credit quality firms than for their low credit quality counterparts.

We also examine whether the relation between debt maturity and growth opportunities is influenced by managerial stock ownership. The need for frequent external monitoring is likely to be greater for low-growth firms because, as shown by Jung, Kim, and Stulz (1996), agency costs of managerial discretion increase with declining investment opportunities. We therefore expect managerial stock ownership to play a prominent role in facilitating external monitoring through the choice of debt maturity in low-growth firms. Hence, the negative relation between debt maturity and managerial stock ownership is expected to be pronounced for firms with low-growth opportunities.

In contrast to low-growth firms, the agency costs of managerial discretion are likely to be lower for high-growth firms because the objectives of managers and shareholders become more aligned with increasing growth opportunities (see Jung et al. (1996)). Moreover, while high-growth firms are typically constrained from borrowing short-term due to liquidity risk, the high risk associated with these firms screens them out of the long end of the maturity spectrum. Therefore, due to the combination of these factors affecting debt maturity choice, the effect of managerial stock ownership on debt maturity is unclear for firms with high-growth opportunities.

\section{Sample Formation and Data Description}

Our objective is to relate the degree of manager-shareholder interest alignment to the debt maturity structure. Because the observed debt maturity structure in a given year is the cumulative result of previous debt maturity choices, an appropriate measure of manager-shareholder interest alignment should reflect the equity-based incentives that influenced past debt maturity decisions. Given that the equity-based compensation awarded in a particular year does not influence past decisions, we use stock ownership as a measure of a manager's cumulative equity-based compensation (net of shares sold) to capture the degree of interest alignment between managers and shareholders. The managerial stock ownership includes common stock and restricted shares and is scaled by the total number of shares outstanding.

To investigate the link between managerial stock ownership and debt maturity, we obtain a sample of firms with available data on both Compustat and 
Standard and Poor's ExecuComp databases spanning the years 1992 through 1999. ExecuComp covers firms in the S\&P 500, S\&P Midcap 400, S\&P SmallCap 600 , and other firms that are not currently in the S\&P indexes but that were previously in one of the indexes. We retrieve managerial stock ownership data from the ExecuComp database. All other financial data are from the Compustat database. Following Barclay and Smith (1995), we restrict our sample to industrial firms by including only firms with Standard Industrial Classification (SIC) codes from 2000 to 5999. Financial firms are excluded because Compustat does not provide debt maturity data for them.

Compustat reports the amount of long-term debt at fiscal year end which is payable in more than 1 year through more than 5 years. To measure the maturity structure of a firm's debt, we discard any firm-year observation where the total debt maturity is less than $0 \%$ or more than $100 \%$. We also eliminate three extreme observations for which the absolute value of abnormal earnings is greater than three. In unreported results, we find that winsorizing these observations does not change our findings. The sample consists of 6,246 firm-year observations representing 1,185 unique firms with ownership data available. The data description and univariate results presented in Tables I-III are based on 6,246 firm-year observations. Given the additional requirement that there be nonmissing data on all variables used in the two-stage least squares regression analysis, our multivariate results are based on 4,514 firm-year observations, representing 991 firms.

\section{A. Debt Maturity Structure}

Panel A of Table I provides descriptive statistics on debt maturity structure for the sample of 6,246 firm-year observations between 1992 and 1999. The table reports the distribution of the percentage of total debt maturing in more than 1 through more than 5 years. ${ }^{3}$ We document that, on average, at least $78 \%$ of total debt matures in more than 1 year, $60.86 \%$ matures in 3 or more years, and $42.62 \%$ in 5 or more years. Comparison of debt maturity structures of our sample firms with those reported in previous studies suggests that firms have lengthened their debt maturity in the 1990s. For example, Barclay and Smith (1995) find that 51.7\% of their sample firms' debt is due in more than 3 years (sample period 1974 to 1992), while the comparable number for Johnson's (2003) study for the period 1986 to 1995 is $46 \%$. The cross-sectional variability of our sample firms' maturity as measured by the $S D(25.12-29.75 \%)$ is similar to that observed by Barclay and Smith (27.2-29.1\%).

\section{B. Firm Characteristics}

Panel B of Table I documents the salient firm characteristics measured as of the fiscal year end. Let MgtOwner be the sum of common and restricted stock

\footnotetext{
${ }^{3}$ In addition to bonds, long-term debt includes other firm obligations such as capitalized lease obligations and long-term fixed claims.
} 


\section{Table I}

\section{Distribution and Descriptive Statistics of Corporate Debt Maturity, 1992-1999}

The sample includes 6,246 firm-year observations between 1992 and 1999, and consists of industrial firms (with SIC code between 2000 and 5999) with available data on both Compustat tapes and Standard and Poor's ExecuComp databases. The percent of total debt maturing from the fiscal year end is from Compustat. The variable MgtOwner is the sum of common and restricted stock owned by the top five executives divided by shares outstanding at the fiscal year end. The variables representing firm characteristics are measured using Compustat data items as follows: Firm Value is the market value of total assets, estimated as (share price (data item 199) $\times$ outstanding shares (data item 54)) + book value of total assets (data item 6) - book value of equity (data item 60); Leverage is defined as long-term debt (data item 9)/market value of total assets; M/B is defined as firm value/book value of total assets (data item 6). Fixed Assets ratio is the ratio of net property, plant, and equipment (data item 8) to total assets (data item 6); Profitability is the ratio of operating income before depreciation (data item 13) to total assets (data item 6); Asset Maturity is defined as (gross property, plant, and equipment (data item 7)/total assets (data item 6)) $\times($ gross property, plant, and equipment (data item 7)/depreciation expense (data item 14)) + (current assets (data item 4)/total assets (data item 6)) $\times$ (current assets (data item 4)/cost of goods sold (data item 41)); Term Structure is measured as the month-end yield on 10-year government bonds - the month-end yield on 6-month government bonds. The yields on government bonds are obtained from the Federal Reserve economic database website. The variable Abnormal Earnings is defined as earnings in year $t+1$ (data item 20) - earnings in year $t$ /(share price (data item 199) $\times$ outstanding shares (data item 54)) in year $t$, and Asset Return StdDev is the stock return $S D$ during the fiscal year $\times$ (market value of equity/market value of assets). Regulated firms are defined as in Barclay and Smith (1995). Operating loss carryforwards is data item 52, and investment tax credit is data item 51.

Panel A: Distribution of Percentage of Total Debt Maturing from the Fiscal Year End

\begin{tabular}{lcccccc}
\hline $\begin{array}{l}\text { Percent of Debt That } \\
\text { Matures in More Than }\end{array}$ & Observations & Mean & $S D$ & $25^{\text {th }}$ Percentile & Median & $7^{\text {th }}$ Percentile \\
\hline 1 year & 6,246 & 78.54 & 25.12 & 71.75 & 87.50 & 96.19 \\
2 years & 6,246 & 69.98 & 27.53 & 58.65 & 78.39 & 90.43 \\
3 years & 6,246 & 60.86 & 29.18 & 43.34 & 67.94 & 83.83 \\
4 years & 6,246 & 52.14 & 29.75 & 29.28 & 56.99 & 76.02 \\
5 years & 6,246 & 42.62 & 29.33 & 15.27 & 45.05 & 65.80 \\
\hline
\end{tabular}

(continued)

owned by the top five executives divided by shares outstanding. All other firm characteristics are defined in Table I. For our sample of 6,246 firm-year observations, the mean managerial stock ownership level of $4.46 \%$ is larger than that reported by Ofek and Yermack (2000). Our sample firms are relatively large with mean (median) total assets of $\$ 7,812.80(\$ 1,894.21)$ million. The mean (median) leverage for our sample is $16.27 \%$ (14.35\%). The sample firms typically have valuable growth opportunities with mean (median) market-tobook assets ratio of 1.80 (1.46). Both the average fixed assets ratio of 0.39 and profitability ratio of 0.15 are slightly larger than those reported by Johnson (2003). The average asset maturity of 12.59 years is more than twice the average in Johnson's study. This result in conjunction with the statistics on debt 
Table I-Continued

\begin{tabular}{|c|c|c|c|c|c|c|}
\hline \multicolumn{7}{|c|}{ Panel B: Descriptive Statistics of Firm Characteristics } \\
\hline & Observations & Mean & $S D$ & $\begin{array}{c}25^{\text {th }} \\
\text { Percentile }\end{array}$ & Median & $\begin{array}{c}75^{\text {th }} \\
\text { Percentile }\end{array}$ \\
\hline MgtOwner (\%) & 6,246 & 4.46 & 8.79 & 0.26 & 0.87 & 3.80 \\
\hline Firm Value (\$millions) & 6,246 & $7,812.80$ & $25,730.69$ & 668.36 & $1,894.21$ & $5,928.09$ \\
\hline Leverage $(\%)$ & 6,246 & 16.27 & 12.69 & 5.90 & 14.35 & 24.21 \\
\hline $\mathrm{M} / \mathrm{B}$ & 6,246 & 1.80 & 1.11 & 1.19 & 1.46 & 2.02 \\
\hline Fixed Assets Ratio & 5,573 & 0.39 & 0.22 & 0.21 & 0.35 & 0.56 \\
\hline Profitability & 5,558 & 0.15 & 0.09 & 0.11 & 0.14 & 0.19 \\
\hline Asset Maturity & 6,246 & 12.59 & 10.33 & 5.28 & 10.60 & 14.92 \\
\hline Term Structure (\%) & 6,246 & 1.24 & 1.00 & 0.36 & 1.06 & 2.21 \\
\hline $\begin{array}{l}\text { Abnormal } \\
\quad \text { Earnings }(\%)\end{array}$ & 5,131 & 0.83 & 13.11 & -1.00 & 1.00 & 2.00 \\
\hline $\begin{array}{l}\text { Asset Return } \\
\text { StdDev (\%) }\end{array}$ & 5,208 & 1.70 & 0.96 & 1.06 & 1.50 & 2.16 \\
\hline $\begin{array}{l}\text { Proportion of } \\
\text { observations that } \\
\text { represent regulated } \\
\text { firms }\end{array}$ & 0.16 & & & & & \\
\hline $\begin{array}{l}\text { Proportion of } \\
\text { observations with } \\
\text { operating loss } \\
\text { carryforwards }\end{array}$ & 0.16 & & & & & \\
\hline $\begin{array}{l}\text { Proportion of } \\
\text { observations with } \\
\text { investment tax } \\
\text { credits }\end{array}$ & 0.13 & & & & & \\
\hline $\begin{array}{l}\text { Proportion of } \\
\text { observations with } \\
\text { bond ratings }\end{array}$ & 0.57 & & & & & \\
\hline
\end{tabular}

maturity suggests that firms have lengthened their debt maturities in the 1990s to match the increase in asset maturity during that period. The mean abnormal earnings indicate that these firms are profitable, on average. Consistent with this result, we find that the proportion of observations representing firms with operating loss carryforwards is 0.16 , which is much lower than the mean of 0.34 reported by Johnson.

\section{Managerial Stock Ownership and Debt Maturity Structure}

Table II explores the relation between managerial stock ownership and debt maturity structure. In Panel A, we partition the sample into ownership quartiles. For each ownership quartile, we report the mean and median percentages of debt maturing in more than 1 year through debt maturing in more than 5 years. Based on the central hypothesis proposed in this study, we expect a negative relation between managerial stock ownership and debt maturity. 


\section{Table II}

\section{Median (Mean) Percentage of Total Debt That Matures from the Fiscal Year End, Categorized by Managerial Stock Ownership}

The sample consists of 6,246 firm-year observations between 1992 and 1999, where MgtOwner is defined as the sum of common and restricted stock owned by the top five executives divided by shares outstanding at the fiscal year end. The number of observations in each quartile is not the same because each year, firms are classified into one of four groups. The Wilcoxon $Z$-statistic is from the rank sum test for difference between the respective distributions. The median (mean) are reported below, with number of observations in brackets. ${ }^{* * *}$ denotes significance at the $1 \%$ level.

Panel A: Percentage of Total Debt Maturing from the Fiscal Year End by Proportion of Top Executive Ownership Quartiles

\begin{tabular}{lccccc}
\hline & \multicolumn{5}{c}{ Debt Maturing in More Than } \\
\cline { 2 - 6 } & 1 Year & 2 Years & 3 Years & 4 Years & 5 Years \\
\hline \multirow{2}{*}{ Lowest ownership quartile } & 84.70 & 77.46 & 69.73 & 62.99 & 54.14 \\
& $(78.87)$ & $(71.67)$ & $(64.30)$ & $(57.16)$ & $(49.66)$ \\
& {$[1,563]$} & {$[1,563]$} & {$[1,563]$} & {$[1,563]$} & {$[1,563]$} \\
Quartile 2 & 86.75 & 78.41 & 69.14 & 58.42 & 47.27 \\
& $(78.84)$ & $(71.40)$ & $(62.76)$ & $(54.17)$ & $(44.94)$ \\
Quartile 3 & {$[1,561]$} & {$[1,561]$} & {$[1,561]$} & {$[1,561]$} & {$[1,561]$} \\
& 89.77 & 80.73 & 69.57 & 56.09 & 42.00 \\
Highest ownership quartile & $(80.44)$ & $(71.53)$ & $(61.81)$ & $(51.92)$ & $(40.86)$ \\
& {$[1,562]$} & {$[1,562]$} & {$[1,562]$} & {$[1,562]$} & {$[1,562]$} \\
& 89.42 & 77.33 & 61.42 & 48.13 & 30.45 \\
& $(75.99)$ & $(65.31)$ & $(54.54)$ & $(45.29)$ & $(34.96)$ \\
& {$[1,560]$} & {$[1,560]$} & {$[1,560]$} & {$[1,560]$} & {$[1,560]$}
\end{tabular}

Test Statistic of Difference between Lowest and Highest Quartiles

\begin{tabular}{lrlrrr}
\hline Wilcoxon's $Z$ & $-5.48^{* * *}$ & 0.51 & $6.05^{* * *}$ & $9.86^{* * *}$ & $14.38^{* * *}$ \\
$t$-Statistic & $3.09^{* * *}$ & $6.29^{* * *}$ & $9.26^{* * *}$ & $11.29^{* * *}$ & $14.37^{* * *}$ \\
\hline
\end{tabular}

Panel B: Pearson Correlation between Ownership and Percent of Debt That Matures from the Fiscal Year End ( $p$-Values in Parentheses)

\begin{tabular}{lccccc}
\hline MgtOwner & -0.063 & -0.118 & -0.150 & -0.163 & -0.179 \\
& $(0.0004)$ & $(0.0001)$ & $(0.0001)$ & $(0.0001)$ & $(0.0001)$
\end{tabular}

The results suggest that managerial stock ownership has a significant impact on the debt maturity choice undertaken by firms. Consistent with our hypothesis, managers with the highest stock ownership utilize the shortest debt maturity structure. Specifically, we find that for debt maturing in more than 5 years, the difference between the means for the highest and lowest ownership quartiles is $\mathbf{1 4 . 7 0}$ percentage points, which is statistically significant at the $1 \%$ level $(t$-statistic $=14.37)$. As shown in the last row of Panel A, the difference between means for the highest and lowest quartiles is statistically significant for all other maturities. Furthermore, the mean and median debt maturity structure is generally monotonically decreasing with managerial stock ownership for percentage of debt maturing in more than 3,4 , and 5 years. 


\section{Table III}

\section{Pearson Correlations among Debt Maturity, Managerial Stock Ownership, Market-to-Book, Bond Rating, and Leverage}

The sample consists of 6,246 firm-year observations between 1992 and 1999, where DEBT3 and DEBT5 refer to the percentage of debt maturing in more than 3 and more than 5 years, respectively. The variable MgtOwner is the sum of common and restricted stock owned by the top five executives divided by shares outstanding at the fiscal year end; $\mathrm{M} / \mathrm{B}$ is defined as firm value/book value of total assets (data item 6); Bond rating is a numeric variable which assumes a value of 1 for AAA through 27 for CCC or below, while nonrated firms are assigned a value of 0 ; and Leverage is defined as long-term debt (data item 9)/market value of total assets. All correlations reported below are significant at the $1 \%$ level.

\begin{tabular}{lrrcrrr}
\hline & DEBT3 & DEBT5 & MgtOwner & M/B & Bond Rating & Leverage \\
\hline DEBT3 & 1.00 & & & & & \\
DEBT5 & 0.74 & 1.00 & & & & \\
MgtOwner & -0.12 & -0.13 & 1.00 & & & \\
M/B & -0.20 & -0.18 & 0.10 & 1.00 & & \\
Bond Rating & 0.35 & 0.35 & -0.17 & -0.20 & 1.00 & 1.00 \\
Leverage & 0.45 & 0.37 & -0.09 & -0.48 & 0.43 & \\
\hline
\end{tabular}

Panel B of Table II presents the correlation between managerial stock ownership and the fraction of debt that matures in more than 1 year to more than 5 years. Consistent with our main hypothesis, the results indicate a significantly negative correlation between debt maturity and managerial stock ownership. The correlations between various debt maturities and managerial stock ownership are negative and significant (ranging from -0.063 to -0.179 ).

Taken together, the univariate analysis presented in Table II suggests that more entrenched managers (i.e., managers with low stock ownership) choose longer maturity debt, thereby insulating themselves from being monitored by the debt market. These results complement the findings of Berger et al. (1997) by illustrating that the role of managerial stock ownership extends beyond the leverage choice by also influencing the firm's debt maturity choice.

In Table III, we present the matrix of Pearson correlation coefficients capturing the simple relations between debt maturity (two measures-DEBT3 and DEBT5, defined as the percentage of debt maturing in more than 3 years and 5 years, respectively), managerial stock ownership (MgtOwner), growth opportunities proxied by the market-to-book assets ratio (M/B), bond rating, and leverage. Based on our central hypothesis and previous studies on debt structure choice, we expect these variables to be important determinants of debt maturity and leverage. These key variables are defined in Tables I and III. We find that all the variables are significantly correlated at the $1 \%$ level and are consistent with our expectations and the findings in previous studies. It is worth noting at the outset that DEBT3 and DEBT5 are highly positively correlated suggesting that the univariate results based on DEBT3 would also hold for DEBT5.

In support of our hypothesis, we find a significant negative correlation between debt maturity and managerial stock ownership. We also document 
that the correlations between growth opportunities (M/B) and debt maturity (DEBT3 and DEBT5) are significantly negative. This result is consistent with Myers' (1977) prediction related to the underinvestment problem. The significantly positive correlations between leverage and debt maturity measures corroborate the results reported by Barclay et al. (2003) and Johnson (2003). ${ }^{4}$ This finding underscores the possibility that leverage and maturity are endogenously determined. The correlations between these key variables suggest that we need to design the multivariate analysis recognizing that debt maturity and leverage are jointly endogenous variables.

\section{Multivariate Analysis}

\section{A. Model Specification and Variable Descriptions}

To test our hypothesis of a negative relation between managerial stock ownership and debt maturity structure in a multivariate framework, we use the two-stage least squares regression analysis. We model leverage and debt maturity as simultaneously determined with maturity as the dependent variable in the second-stage regression and leverage estimated endogenously in the firststage regression. Berger et al. (1997) document a positive relation between leverage and managerial stock ownership. Therefore, for the first-stage regression model with leverage as the endogenous variable, we use managerial stock ownership as one of the independent variables. Other variables used to determine leverage in the first stage are Log of Firm Value, M/B ratio, Fixed Assets ratio, Profitability, Abnormal Earnings, Asset Return StdDev, NOL dummy, ITC dummy, and Regulation dummy. These variables are defined in Tables I and IV. The motivation to control for the effects of these variables on leverage is based on the predictions of theoretical models of debt maturity and capital structure, and the empirical findings in Johnson (2003) and Barclay and Smith (1995), among others. For the sake of brevity, we refer the reader to previous studies for our motivation to include these variables.

In the second-stage regression, we control for leverage using the predicted leverage from the first-stage regression. To properly identify the system of equations, in the second-stage regression, we exclude Fixed Assets ratio, Profitability, NOL dummy, and ITC dummy. Based on Smith and Watts (1992) and Barclay and Smith (1995), we expect a positive relation between leverage and debt maturity. Following Myers (1977), we control for asset maturity by using the book value-weighted measure defined in Stohs and Mauer (1996) and Johnson (2003). We expect a positive coefficient for Asset Maturity if firms match the maturities of their assets and liabilities. As predicted by Myers (1977), we expect a negative coefficient for M/B since firms are expected to use shorter maturity debt to minimize their underinvestment problems.

\footnotetext{
${ }^{4}$ Following Barclay and Smith (1995), we measure debt maturity as the proportion of total debt maturing in more than 3 years (DEBT3) and 5 years (DEBT5). Johnson's (2003) measure of debt maturity is the complement of our measure, and therefore, he reports a negative correlation between leverage and maturity.
} 


\section{Table IV}

\section{Second-Stage Regression Coefficients Explaining the Percentage of Total Debt That Matures in More Than 3 Years}

The table shows the second-stage regression results from a two-stage least squares regression model. The dependent variable for the second-stage regression is DEBT3. The variable MgtOwner is defined as the sum of common and restricted stock owned by the top five executives divided by shares outstanding at the fiscal year end. Investment grade dummy is assigned the value 1 for investment grade firms and 0 otherwise. $\mathrm{M} / \mathrm{B}$ dummy is 1 if the market-to-book ratio is less than the corresponding industry median $\mathrm{M} / \mathrm{B}$ ratio (based on two-digit SIC code), and 0 otherwise. The predicted leverage is from the first-stage regression where the dependent variable is Leverage. Regulation dummy is 1 for regulated firms and 0 otherwise. Rating dummy is assigned the value 1 for rated firms and 0 for nonrated firms. The independent variables in the first-stage regression are MgtOwner, M/B, Log of Firm Value, Regulation Dummy, Fixed Assets Ratio, Profitability, Abnormal Earnings, Asset Return StdDev, NOL Dummy, and ITC Dummy. Regulation dummy assumes a value of 1 if the firm is regulated, and 0 otherwise. NOL dummy and ITC dummy take on the value of 1 for firms with operating loss carryforwards and investment tax credits respectively, and 0 otherwise. All remaining variables are defined in Table I. White's (1980) heteroskedasticity consistent $t$-statistics are reported in parentheses. The number of observations is based on available data for all variables. ${ }^{* * *},{ }^{* *}$, and ${ }^{*}$ denote significance at the $1 \%, 5 \%$, and $10 \%$ levels, respectively.

\begin{tabular}{|c|c|c|c|c|c|}
\hline Independent Variables & $\begin{array}{l}\text { Predicted } \\
\text { Signs }\end{array}$ & Pooled 1 & Pooled 2 & $\begin{array}{c}\text { Cross- } \\
\text { Sectional }\end{array}$ & $\begin{array}{c}\text { Fixed } \\
\text { Effects }\end{array}$ \\
\hline Intercept & & $\begin{array}{l}-27.95 \\
(-2.57)^{* * *}\end{array}$ & $\begin{array}{l}-28.65 \\
(-2.63)^{* * *}\end{array}$ & $\begin{array}{l}-21.73 \\
(-1.07)\end{array}$ & \\
\hline MgtOwner & - & $\begin{array}{l}-20.72 \\
(-4.35)^{* * *}\end{array}$ & $\begin{array}{l}-10.56 \\
(-1.91)^{*}\end{array}$ & $\begin{array}{l}-17.09 \\
(-2.15)^{* *}\end{array}$ & $\begin{array}{l}-33.08 \\
(-3.45)^{* * *}\end{array}$ \\
\hline $\begin{array}{l}\text { MgtOwner } * \text { Investment } \\
\text { grade dummy }\end{array}$ & - & & $\begin{array}{l}-43.47 \\
(-2.74)^{* * *}\end{array}$ & & \\
\hline MgtOwner $*$ M/B dummy & - & & $\begin{array}{l}-24.94 \\
(-2.67)^{* * *}\end{array}$ & & \\
\hline Leverage (predicted) & + & $\begin{array}{l}116.81 \\
(8.57)^{* * *}\end{array}$ & $\begin{array}{l}119.02 \\
(8.70)^{* * *}\end{array}$ & $\begin{array}{l}155.19 \\
(5.36)^{* * *}\end{array}$ & $\begin{array}{l}55.38 \\
(3.22)^{* * *}\end{array}$ \\
\hline Asset Maturity & + & $\begin{array}{c}0.08 \\
(1.57)\end{array}$ & $\begin{array}{c}0.07 \\
(1.35)\end{array}$ & $\begin{array}{l}-0.05 \\
(-0.46)\end{array}$ & $\begin{array}{l}0.15 \\
(1.70)^{*}\end{array}$ \\
\hline $\mathrm{M} / \mathrm{B}$ & - & $\begin{array}{l}1.72 \\
(2.37)^{* *}\end{array}$ & $\begin{array}{l}1.65 \\
(2.27)^{* *}\end{array}$ & $\begin{array}{l}2.42 \\
(1.86)^{*}\end{array}$ & $\begin{array}{l}0.20 \\
(0.22)\end{array}$ \\
\hline Log of Firm Value & + & $\begin{array}{l}16.92 \\
(7.08)^{* * *}\end{array}$ & $\begin{array}{l}17.08 \\
(7.12)^{* * *}\end{array}$ & $\begin{array}{l}14.24 \\
(3.32)^{* * *}\end{array}$ & $\begin{array}{l}7.96 \\
(2.03)^{* *}\end{array}$ \\
\hline$(\text { Log of Firm Value })^{2}$ & - & $\begin{array}{l}-1.09 \\
(-7.39)^{* * *}\end{array}$ & $\begin{array}{l}-1.10 \\
(-7.43)^{* * *}\end{array}$ & $\begin{array}{l}-0.93 \\
(-3.50)^{* * *}\end{array}$ & $\begin{array}{l}-0.24 \\
(-0.93)\end{array}$ \\
\hline Term Structure & + & $\begin{array}{l}-1.06 \\
(-2.80)^{* * *}\end{array}$ & $\begin{array}{l}-1.09 \\
(-2.88)^{* * *}\end{array}$ & $\begin{array}{l}-4.01 \\
(-2.96)^{* * *}\end{array}$ & $\begin{array}{c}0.40 \\
(1.29)\end{array}$ \\
\hline Regulation Dummy & + & $\begin{array}{l}-1.08 \\
(-0.80)\end{array}$ & $\begin{array}{l}-1.39 \\
(-1.02)\end{array}$ & $\begin{array}{l}-3.38 \\
(-1.29)\end{array}$ & \\
\hline Abnormal Earnings & - & $\begin{array}{c}2.46 \\
(0.76)\end{array}$ & $\begin{array}{c}2.22 \\
(0.68)\end{array}$ & $\begin{array}{c}0.79 \\
(0.07)\end{array}$ & $\begin{array}{c}2.79 \\
(1.16)\end{array}$ \\
\hline Asset Return StdDev & - & $\begin{array}{l}-60.18 \\
(-0.95)\end{array}$ & $\begin{array}{l}-66.81 \\
(-1.05)\end{array}$ & $\begin{array}{l}-74.19 \\
(-0.58)\end{array}$ & $\begin{array}{l}-267.80 \\
\quad(-3.30)^{* * *}\end{array}$ \\
\hline Rating Dummy & + & $\begin{array}{l}11.68 \\
(11.95)^{* * *}\end{array}$ & $\begin{array}{l}12.28 \\
(12.28)^{* * *}\end{array}$ & $\begin{array}{l}15.96 \\
(7.93)^{* * *}\end{array}$ & $\begin{array}{l}11.31 \\
(8.10)^{* * *}\end{array}$ \\
\hline$R_{\text {adjusted }}^{2}$ & & 20.24 & 20.44 & 32.53 & 4.31 \\
\hline$F$-Statistic & & 105.11 & 90.17 & 44.39 & 21.33 \\
\hline$p$-Value & & 0.00 & 0.00 & 0.00 & 0.00 \\
\hline Observations & & 4,514 & 4,514 & 991 & 4,514 \\
\hline
\end{tabular}


Following Barclay et al. (2003) and Johnson (2003), we use firm size and its square to control for the effect of credit quality on debt maturity. Diamond (1991) predicts a positive coefficient for firm size since larger firms have higher credit quality and can obtain long-term debt, whereas small firms are screened out of the long end of the maturity spectrum. The nonlinear relation predicted by Diamond implies that the square of firm size is expected to have a negative coefficient.

Based on the tax hypothesis proposed by Barclay and Smith (1995), we expect a positive coefficient for the Term Structure variable. Similarly, the Regulation Dummy variable is expected to have a positive sign, which indicates that regulated firms (dummy variable assigned a value of 1) are expected to have longer maturity debt in comparison to unregulated firms (assigned a value of 0 ).

Following Barclay and Smith, we include the control variable Abnormal Earnings. We expect a negative coefficient for this variable as higher quality firms will be more willing than lower quality firms to subject themselves to more frequent monitoring associated with short-term debt (Flannery (1986)). We also control for asset return $S D$ since firms with greater volatility may be associated with greater credit risk and, hence, may be screened out of the long end of the maturity spectrum. To be consistent with previous studies, the coefficient of this variable should be negative.

\section{B. Multivariate Results}

Table IV presents two pooled, one cross-sectional, and one fixed effects model from the second-stage regression estimation using percentage of debt maturing in more than 3 years (DEBT3) as the explanatory variable, with predicted leverage estimated from the first stage as one of the control variables. We estimate the cross-sectional regression to address the potential concern that the errors in the pooled regressions are unlikely to be independent, hence biasing the $t$-statistics upward. We also estimate a fixed effects regression model to capture time-series variation in the data and provide an alternate specification that addresses the potential serial correlation effect. As discussed above, our regression models incorporate control variables that have been shown in previous studies to be important determinants of corporate debt maturity. We mainly focus on the results presented in Table IV based on the debt maturity measure using the 3-year cutoff, DEBT3.

\section{B.1. Managerial Stock Ownership and Debt Maturity}

In support of our central hypothesis, we find that the coefficients of the focus variable, MgtOwner, are significantly negative in all the models presented in Table IV. We estimate the economic significance of our results by computing the incremental impact of a change in MgtOwner on the debt maturity structure of firms. Specifically, the coefficient in Pooled 1 regression of Table IV indicates that an increase in managerial stock ownership from the median $(0.87 \%)$ to the $95^{\text {th }}$ percentile $(24.54 \%)$ is expected to shorten the percentage of total debt maturing in more than 3 years by $4.90 \%$. 
Diamond (1991) posits that investment grade firms (i.e., firms with low liquidity risk) are expected to choose short-maturity debt. We extend this proposition by reasoning that among investment grade firms, those with low managerial stock ownership are expected to choose longer maturity debt than their counterparts with high managerial ownership. To test this hypothesis, we include the interaction term MgtOwner $*$ Investment grade dummy in our secondstage regression. Investment grade dummy assumes a value of 1 for firms with investment grade debt, and 0 otherwise. Based on our hypothesis, we expect the coefficient of this interaction term to be negative.

In the regression model Pooled 2 (Table IV), we find that the coefficient of this interaction term is significantly negative. The economic implication of this result is that for investment grade firms, an increase in MgtOwner from the median to the $95^{\text {th }}$ percentile will lower the percentage of debt maturing in more than 3 years by $10.29 \%$. This reduction for investment grade firms is in addition to the direct effect of MgtOwner on DEBT3. The significant negative coefficient for this interaction term supports our proposition extending Diamond's (1991) liquidity risk theory of debt maturity by showing that even among firms with low liquidity risk (investment grade debt), the debt maturity choice depends on the degree of manager-shareholder interest alignment.

We also examine whether the negative relation between debt maturity and managerial stock ownership is pronounced for firms with low-growth opportunities by including the interaction term MgtOwner $* \mathrm{M} / \mathrm{B}$ dummy in the Pooled 2 regression. The M/B dummy assumes a value of 1 for low-growth firms, and 0 otherwise. We reason that growth opportunities are industry specific rather than sample specific, and we classify firms as low growth if their $\mathrm{M} / \mathrm{B}$ ratio is less than the corresponding industry median $\mathrm{M} / \mathrm{B}$ ratio (based on two-digit SIC code). ${ }^{5}$

In support of our hypothesis, we find that the coefficient of the interaction term, MgtOwner $* \mathrm{M} / \mathrm{B}$ dummy, is significantly negative in the regression model Pooled 2 in Table IV. Our results indicate that for low-growth option firms, an increase in MgtOwner from the median to the $95^{\text {th }}$ percentile results in a $5.90 \%$ reduction in DEBT3, in addition to the stand-alone effect of MgtOwner on debt maturity. 6

\footnotetext{
${ }^{5} \mathrm{Using}$ the sample median $\mathrm{M} / \mathrm{B}$ ratio can result in misclassification of firms because those below (above) the median will be classified as low (high) growth even if their M/B ratio is higher (lower) than their corresponding industry median M/B. Servaes (1991) uses a similar reasoning in classifying firms as high or low Tobin's Q. We note that the interaction term MgtOwner $* \mathrm{M} / \mathrm{B}$ dummy is insignificant when the sample median $\mathrm{M} / \mathrm{B}$ ratio is used to classify firms as high or low growth.

${ }^{6}$ We do not include the interaction terms in the cross-sectional and fixed effects regressions because the classification of the dummy variable as 0 or 1 for a given firm can change over time. As a result, the average of the dummy variable may no longer be binary. This precludes us from strictly classifying firms as belonging to one category or the other in a cross-sectional and fixed effects framework. Therefore, the interpretation of the interaction term consisting of a binary dummy variable is unclear in these specifications.
} 


\section{B.2. Control Variables}

Consistent with the results in Johnson (2003), Leverage (predicted) is positive and highly significant in all the models, indicating that debt maturity increases with leverage. ${ }^{7}$ As discussed above, Asset Maturity is expected to be positive if firms match the maturities of their assets and liabilities. While the coefficients of this control variable are generally positive, they are insignificant in Table IV. Contrary to the findings of Barclay et al. (2003), the coefficient of the growth opportunity variable (M/B) is significantly positive in all the models. This result, however, is consistent with both Johnson (2003) and the original findings of Stohs and Mauer (1996). As expected, the coefficients of Log of Firm Value are significantly positive, while the coefficients of (Log of Firm Value $)^{2}$ are significantly negative in all the models, except in the fixed effects regressions. These results are consistent with the nonlinear relation between debt maturity and credit quality predicted by Diamond (1991).

Based on the discussion in Section III.A, we also include Term Structure, Regulation dummy, Abnormal Earnings, Asset Return StdDev, and Rating dummy as additional control variables in the second-stage regression. ${ }^{8}$ The coefficients of the Term Structure variable are significantly negative in Table IV. We find that the coefficients of the Regulation dummy and Abnormal Earnings are generally insignificant. As expected, the Rating dummy, which is 1 for rated firms and 0 otherwise, is positive and highly significant in all models.

Overall, after controlling for all the previously known determinants of debt maturity and modeling leverage and debt maturity as simultaneous endogenous variables, we document strong empirical support for our hypothesis predicting an inverse relation between managerial stock ownership and debt maturity. Extending Diamond's (1991) prediction on the relation between liquidity risk and debt maturity, we find support for our proposition that even among firms with low liquidity risk (investment grade firms), the debt maturity choice depends on managerial stock ownership (or the degree of manager-shareholder interest alignment). Our analysis also supports the proposition that the inverse relation between managerial stock ownership and debt maturity is pronounced for firms with low-growth options as compared to their high-growth counterparts.

\section{B.3. Robustness Checks}

B.3.1. Alternative Proxy for Debt Maturity. To check the robustness of our results in Table IV, we repeat the analysis using the percentage of debt maturing in more than 5 years (DEBT5) as the dependent variable. The results, not reported for the sake of brevity, are qualitatively similar to our findings and

\footnotetext{
${ }^{7}$ While we define leverage as the ratio of long-term debt to market value of the firm, our conclusions remain unchanged if leverage is defined as the ratio of total debt to market value of the firm.

${ }^{8}$ Our results are similar when we follow Johnson (2003) and include NOL and ITC dummies in the second-stage regression.
} 
economic implications based on DEBT3. Specifically, the coefficients of the focus variable, MgtOwner, are significantly negative in all the models using this alternative measure of debt maturity, except in the cross-sectional regression. We also find that the coefficients of the control variables, Asset Maturity, Term Structure, Regulation dummy, and Abnormal Earnings, are generally significant with the predicted sign when DEBT5 is used as a measure of debt maturity.

B.3.2. Alternative Measure of Liquidity Risk. Following Johnson (2003), we use the asset return $S D$ as an alternative measure of credit risk. We redefine the Investment grade dummy variable by assigning a value of 1 for firms with below median asset return $S D$, and 0 otherwise. The results obtained using the interaction term, MgtOwner $*$ Investment grade dummy, remain robust to this alternative specification.

B.3.3. Alternative Measures of Growth Opportunities. To test the robustness of our results based on the interaction term MgtOwner $* \mathrm{M} / \mathrm{B}$ dummy, we examine several alternative specifications for this interaction term. First, we use the ratio of capital expenditures and $R \& D$ expenses to total assets as an alternative measure of growth opportunities. Similar to our classification using the M/B ratio, we group firms as low or high growth based on the industry median ratio of capital expenditures and $R \& D$ expenses to total assets. We find that our result using the $\mathrm{M} / \mathrm{B}$ ratio is maintained when this alternative measure of growth opportunities is used. Second, in the spirit of Lang, Stulz, and Walkling (1989) and Lang and Litzenberger (1989), we use a cutoff of one for the M/B ratio to classify firms as high or low growth. The result using this classification method is qualitatively similar to the result obtained when the industry median $M / B$ ratio is used. Our results are also robust (statistically significant at the $5 \%$ level or better) when we use the ratio of $R \& D$ expense to sales and the earnings-price ratio as two alternative proxies for growth opportunities.

\section{Summary and Conclusions}

This is the first study to document that managerial stock ownership plays a significant role in determining corporate debt maturity. The corporate finance literature has established that financing decisions, such as the choice of leverage and debt maturity, are important mechanisms to monitor managers when there is separation of ownership and control. However, these crucial financing decisions are at the discretion of top managers who, previous studies assume, choose the optimal debt maturity and self-impose monitoring. We reason that the agency problem of managerial discretion in the choice of debt maturity, heretofore ignored in the capital structure literature, can lead to a suboptimal debt maturity structure choice in the absence of strong manager-shareholder interest alignment.

We show that managers with higher stock ownership choose a larger proportion of short-maturity debt thereby committing to more frequent monitoring. 
On the other hand, more entrenched managers (i.e., managers with lower stock ownership) choose longer maturity debt. It is important to note that this significant and robust inverse relation between managerial stock ownership and corporate debt maturity emerges after controlling for all previously identified determinants of debt maturity and modeling debt maturity and leverage as jointly endogenous variables. The results strongly support our central proposition that managerial stock ownership is an important determinant of corporate debt maturity. This evidence extends the findings of Berger et al. (1997) that managerial stock ownership plays a role in determining corporate leverage.

This study extends the debt structure literature in two additional ways. First, it refines our understanding of the relation between debt maturity and liquidity risk. Specifically, we extend Diamond's (1991) prediction by showing that managers with low-stock ownership use longer maturity debt even when liquidation risk is low. Second, we examine the influence of managerial stock ownership on the relation between debt maturity and growth opportunities of the firm. We find that for firms with low-growth opportunities, managers with high-stock ownership choose a significantly greater proportion of short-maturity debt than their counterparts with low equity ownership.

\section{REFERENCES}

Barclay, Michael, Leslie Marx, and Clifford W. Smith Jr., 2003, The joint determination of leverage and maturity, Journal of Corporate Finance 9, 149-167.

Barclay, Michael J., and Clifford W. Smith Jr., 1995, The maturity structure of corporate debt, Journal of Finance 50, 609-631.

Berger, Phillip, Eli Ofek, and David Yermack, 1997, Managerial entrenchment and capital structure, Journal of Finance 52, 1411-1438.

Diamond, Douglas, 1991, Debt maturity structure and liquidity risk, Quarterly Journal of Economics 106, 709-737.

Flannery, Mark, 1986, Asymmetric information and risky debt maturity choice, Journal of Finance 41, 18-38.

Grossman, Sanford, and Oliver Hart, 1982, Corporate financial structure and managerial incentives, in J. McCall, ed.: The Economics of Information and Uncertainty (University of Chicago Press, Chicago, Ill).

Guedes, Jose, and Tim Opler, 1996, The determinants of the maturity of corporate debt issues, Journal of Finance 51, 1809-1833.

Jensen, Michael C., 1986, Agency costs of free cash flow, corporate finance, and takeovers, American Economic Review 76, 323-329.

Jensen, Michael, and William Meckling, 1976, Theory of the firm: Managerial behavior, agency costs and ownership structure, Journal of Financial Economics 3, 305-360.

Johnson, Shane A., 2003, Debt maturity and the effects of growth opportunities and liquidity risk on leverage, Review of Financial Studies 16, 209-236.

Jung, Kooyul, Yong-Cheol Kim, and René Stulz, 1996, Timing, investment opportunities, managerial discretion, and the security issue decision, Journal of Financial Economics 42, 159-185.

Kale, Jayant, and Tom Noe, 1990, Risky debt maturity choice in a sequential equilibrium, Journal of Financial Research 13, 155-165.

Lang, Larry, and Robert Litzenberger, 1989, What information is contained in the dividend announcement? Journal of Financial Economics 24, 181-191.

Lang, Larry, René Stulz, and Ralph Walkling, 1989, Managerial performance, Tobin's q and the gains from successful tender offers, Journal of Financial Economics 24, 137-154. 
Myers, Stewart, 1977, Determinants of corporate borrowing, Journal of Financial Economics 5, 147-175.

Novaes, Walter, and Luigi Zingales, 1995, Capital structure choice when managers are in control: Entrenchment versus efficiency, Working paper, University of Chicago.

Ofek, Eli, and David Yermack, 2000, Taking stock: Equity-based compensation and the evolution of managerial stock ownership, Journal of Finance 55, 1367-1384.

Rajan, Raghuram, and Andrew Winton, 1995, Covenants and collateral as incentives to monitor, Journal of Finance 50, 1113-1146.

Servaes, Henri, 1991, Tobin's Q and the gains from takeovers, Journal of Finance 46, 409-419.

Smith, Clifford, and Ross Watts, 1992, The investment opportunity set and corporate financing, dividend, and compensation policies, Journal of Financial Economics 32, 263-292.

Stohs, Mark H., and David C. Mauer, 1996, The determinants of corporate debt maturity structure, Journal of Business 69, 279-312.

Stulz, René, 1990, Managerial discretion and optimal financing policies, Journal of Financial Economics 26, 3-28.

Stulz, René, 2000, Does financial structure matter for economic growth? A corporate finance perspective, Working paper, Ohio State University.

White, Halbert, 1980, A heteroskedasticity-consistent covariance matrix estimator and a direct test for heteroskedasticity, Econometrica 48, 817-838. 